\title{
Sistem Informasi Penerimaan Siswa Baru Berbasis Web Pada SMK Tinta Emas Indonesia Bekasi
}

\section{Annisa Rahmawati ${ }^{1}$, Syahbaniar Rofiah ${ }^{2,{ }^{*}}$}

* Korespondensi: e-mail: rsyahbaniar@gmail.com

\begin{abstract}
1 Sistem Informasi; Universitas Bina Insani; JI. Raya Siliwangi No 6 Rawa Panjang Bekasi Timur 17114 Indonesia, Telp (021) 82436886 / (021) 82436996. $\begin{array}{lllll}\text { Fax } & \text { (021) } & 824 & 009 & 24 ;\end{array}$ annisarahmawati@gmail.com

2 Teknik Informatika; Institut Bisnis Muhammadiyah; Kampus A: Kavling 17A No. 16 Jalan Sersan Aswan RT 002/009 Margahayu Bekasi Timur, 087784621166; email: rsyahbaniar@gmail.com
\end{abstract}

$\begin{array}{ll}\text { Submitted } & \text { : } 5 \text { Agustus } 2021 \\ \text { Revised } & : \text { 10 September } 2021 \\ \text { Accepted } & : \text { 6 Oktober } 2021 \\ \text { Published } & : \text { 30 November } 2021\end{array}$

\begin{abstract}
The development of application technology is used as a means of increasing information in all fields of business, both in the field of education. Admission of new students is the initial stage in the selection process in selecting good students. The problem that occurs at SMK Tinta Emas Indonesia is that there is no information system to record reports in new student admissions. Previously, using bookkeeping and Microsoft excel, it was less effective. The method used is the System Development Life Cycle (SDLC). The results of this study are a webbased new admissions information system. With the admission information system, new students can see announcements and schedules without coming directly to school, and can access reports quickly so that it is effective and does not take much time.
\end{abstract}

Keywords: Education, School, SDLC.

\section{Abstrak}

Perkembangan teknologi aplikasi dimanfaatkan sebagai sarana peningkatan informasi disemua bidang usaha, baik bidang pendidikan. Penerimaan siswa baru merupakan tahap awal dalam proses seleksi dalam memilih peserta didik yang baik. Permasalahan yang terjadi pada SMK Tinta Emas Indonesia belum adanya sistem informasi untuk melakukan pencatatan laporan dalam penerimaan siswa baru. Sebelumnya menggunakan pencatatan melalui buku dan Microsoft excel sehingga kurang efektif. Metode yang digunakan yaitu System Development Life Cycle (SDLC). Hasil dalam penelitian ini yaitu sistem informasi penerimaan siswa baru berbasis web. Dengan adanya sistem informasi penerimaan siswa baru dapat melihat pengumuman dan jadwal tanpa datang langsung ke sekolah, dan dapat mengakses laporan secara cepat sehingga efektif dan tidak memerlukan banyak waktu.

Kata kunci: Pendidikan, SDLC, Sekolah. 


\section{Pendahuluan}

Pendidikan memang berkaitan erat dengan perubahan kelakuan dan perkembangan anak didik. Pendidikan juga merupakan proses transmisi pengetahuan, sikap, perilaku, kepercayaan keterampilan dan aspek-aspek kelakuan lainnya kepada generasi muda. Fungsi dan tujuan pendidikan secara umum memiliki sifat universal. Tujuan pendidikan sangat tergantung pada isi, proses dan pendidikan (Jelantik, 2015).

Penerimaan siswa baru merupakan tahap awal dalam proses seleksi dalam memilih peserta didik yang baik. Dalam memilih peserta didik diperlukan seleksi sesuai dengan standar sekolah misalkan tes ujian masuk untuk melihat apakah siswa tersebut kompetensi dasar intelektual yang baik. Sehingga pada saat memasuki belajar mengajar tidak ada kendala dalam komunikasi penyampaian.

Sekolah Menengah Kejuruan Tinta Emas Indonesia Bekasi saat ini dalam proses penerimaan siswa baru dan ujian masuk dicatat menggunakan Microsoft excel sehingga memungkinkan terjadi kesalahan dan kekurangan data pada saat pencatatan. Hal tersebut merupakan kendala bagi panitia penerimaan siswa baru dalam mengolah data siswa baru sehingga membutuhkan waktu lama dalam memproses data. Sistem yang baik diawali dengan membuat model sistem terlebih dahulu dan penyimpanan data terstruktur.

Dalam penelitian sebelumya menyebutkan, Kemajuan dan perkembangan teknologi informasi saat ini sangat pesat. Demikian pula halnya dengan dunia pendidikan yang selayaknya harus pula selalu mengalami perkembangan (Utomo \& Ariyanti, 2014), dengan mengunakan teknologi web, sistem bisa bekerja dengan intranet, sedangkan informasi untuk publik bisa diupdate pada periode waktu tertentu. Dengan cara ini informasi bisa didapatkan secara cepat dengan pergerakan data yang bisa selalu diikuti (Widianto \& Yulianto, 2014). Dengan adanya Sistem Informasi berbasis komputerisasi dan aplikasi basis data diharapkan dapat membantu penyampaian informasi dan mempermudah dalam pelaksanaan pengolahan dan pengelolaan data penerimaan siswa baru (Kholifah \& Wardati, 2014), adanya sebuah aplikasi yang dapat memberi kemudahan akses informasi dan proses pendaftaran sehingga proses administrasi penerimaan siswa baru menjadi lebih efektif dan efisisen (Witanto \& Solihin, 2016).

Berdasarkan penelitian-penelitian tersebut penulis mengambil kesimpulan bahwa sistem penerimaan siswa baru secara konvensional tidak terlalu efektif dan efisien karena membutuhkan waktu yang lama. Dengan menggunakan sistem penerimaan berbasis website akan memudahkan dalam proses pendaftaran siswa baru.

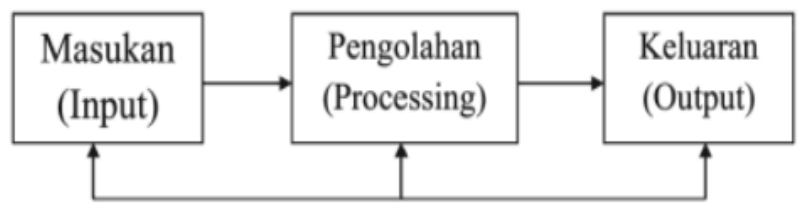

Sumber: Muslihudin \& Oktafianto (2016)

Gambar 1. Model Sistem 
Gambar 1 menunjukkan bahwa sistem atau pendekatan sistem minimal harus mempunyai empat komponen yakni masukan, pengolahan, keluaran dan balikan atau control (Muslihudin \& Oktafianto, 2016).

Suatu sistem memiliki karakteristik tertentu, yang menjelaskan bahwa hal tersebut bisa dikatakan sebagai suatu sistem. Adapun yang termasuk ke dalam karakteristik sistem adalah sebagai berikut: komponen sistem, batasan sistem, lingkungan luar sistem, penghubung sistem, masukan sistem, keluaran sistem, pengolahan sistem dan sasaran sistem (Yasin, 2012).

Sebuah database management system (DBMS) adalah data yang saling berhubungan yang dikelompokkan dalam sebuah tabel atau beberapa tabel dan sebuah aplikasi program yang mengatur cara mengakses data tersebut (Widodo \& Kurnianingtyas, 2017).

Use Case Diagram merupakan permodelan untuk kelakuan (behavior) sistem informasi yang akan dibuat. Use Case Diagram mendeskripsikan sebuah interaksi antara satu atau lebih aktor dengan sistem informasi yang akan dibuat. Dapat dikatakan use case digunakan untuk mengetahui fungsi apa saja yang ada di dalam sistem informasi dan siapa saja yang berhak menggunakan fungsi-fungsi tersebut (Sukamto \& Shalahuddin, 2014).

Batasan masalah yang akan dibahas yaitu sumber data hanya diperoleh dari SMK Tinta Emas Indonesia, sistem yang dirancang menggunakan metode pengembangan $S D L C$, sistem penerimaan siswa hanya meliputi data siswa baru, data penerimaan siswa, data hasil tes siswa dan laporan penerimaan siswa baru.

Berdasarkan latar belakang masalah dapat dirumuskan permasalahannya yaitu Bagaimana membangun sistem penerimaan siswa baru pada SMK Tinta Emas Indonesia Bekasi?; Bagaimana mengoptimalkan penyusunan laporan secara efektif?

Maka untuk meningkatkan keamanan penyimpanan data, otomatisasi penghitungan nilai test, serta kemudahan pemberian informasi penerimaan siswa baru diperlukan sebuah aplikasi sistem informasi penerimaan siswa baru pada Sekolah Menengah Kejuruan Tinta Emas Indonesia Bekasi berbasis web, sehingga calon siswa dapat memperoleh pelayanan yang maksimal dalam pemberian informasi sekolah dan hasil seleksi siswa baru.

\section{Metode Penelitian}

Dalam penellitian ini teknik pengumpulan data yang digunakan yaitu tahap pertama observasi dengan mendatangi langsung SMK Tinta Emas Indonesia Bekasi, tahap kedua wawancara dengan staf tata usaha yang berhubungan langsung dengan penerimaan siswa baru, tahap ketiga studi pustaka dengan membaca literatur yang sesuai dengan tema penelitian. Untuk metode penelitian yang digunakan yaitu System Development Life Cycle (SDLC). Model SDLC air terjun (waterfall) sering juga disebut model sekuensial linier (sequential linear) atau alur hidup klasik (classic life cycle). Model air terjun menyediakan alur hidup perangkat lunak secara sekuensial atau terurut dimulai dari analisis, desain, pengodean, pengujian, dan tahap pendukung (support) (Fathansyah, 2015). 


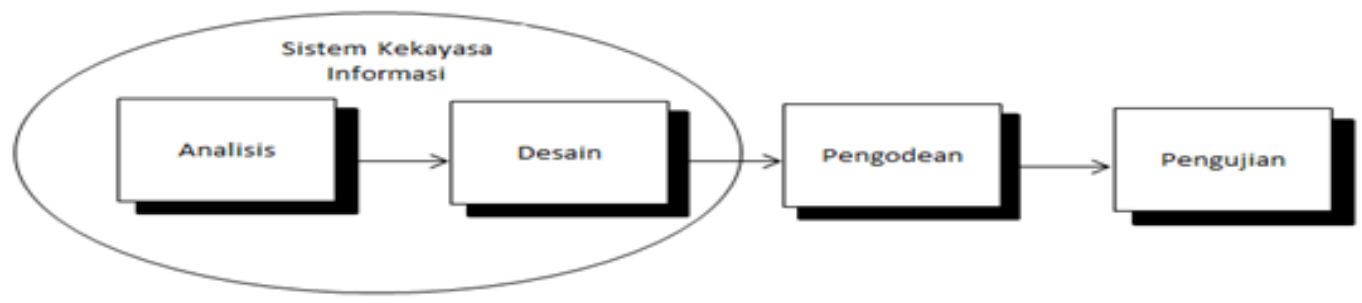

Sumber: Fathansyah (2015)

Gambar 2. Model Pengembangan SDLC

Dalam merancang sistem informasi penerimaan siswa baru pada SMK Tinta Emas Indonesia berikut tahapannya: (a) Analisis dengan menganalisis, kebutuhan dan perangkat pengguna seperti sistem operasi yang dapat berjalan pada web; (b) Desain pada tahap ini membuat desain menggunakan activity diagram, sequence diagram dan class diagram; (c) Pengkodean pada tahap ini perangkat lunak yang digunakan yaitu sublime text 3, PHP, HTML, Codeigniter, CSS dan MySQL; (d) Pengujian pada tahap ini menggunakan Black Box Testing. Pada gambar 3 merupakan kerangka pemikiran penelitian.

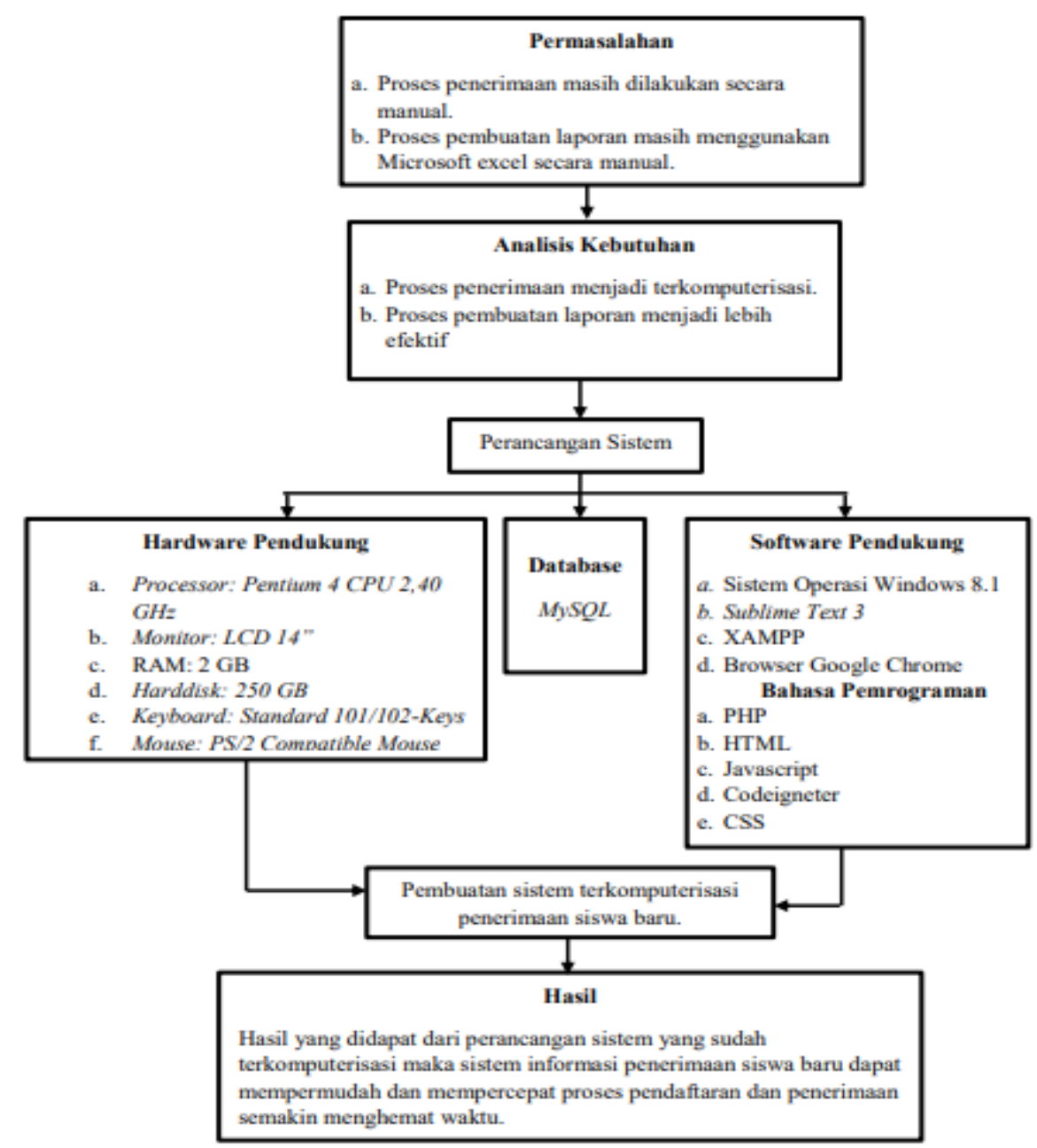

Sumber: Hasil Penelitian (2019)

Gambar 3. Kerangka Pemikiran Penelitian 


\section{Hasil dan Pembahasan}

Hasil dan pembahasan meliputi perencanaan sistem, proses bisnis sistem berjalan, entity relation diagram (ERD), Sequence diagram dan activity diagram.

\subsection{Perencanaan Sistem}

Perencanaan sistem yang peneliti lakukan yaitu mengnalisa proses-proses sistem yang berjalan pada perusahaan yaitu proses bisnis sistem.

\section{Proses Bisnis Sistem Berjalan}

Sebelum melakukan pendaftaran, calon siswa datang ke ruang pendaftaran terlebih dahulu.

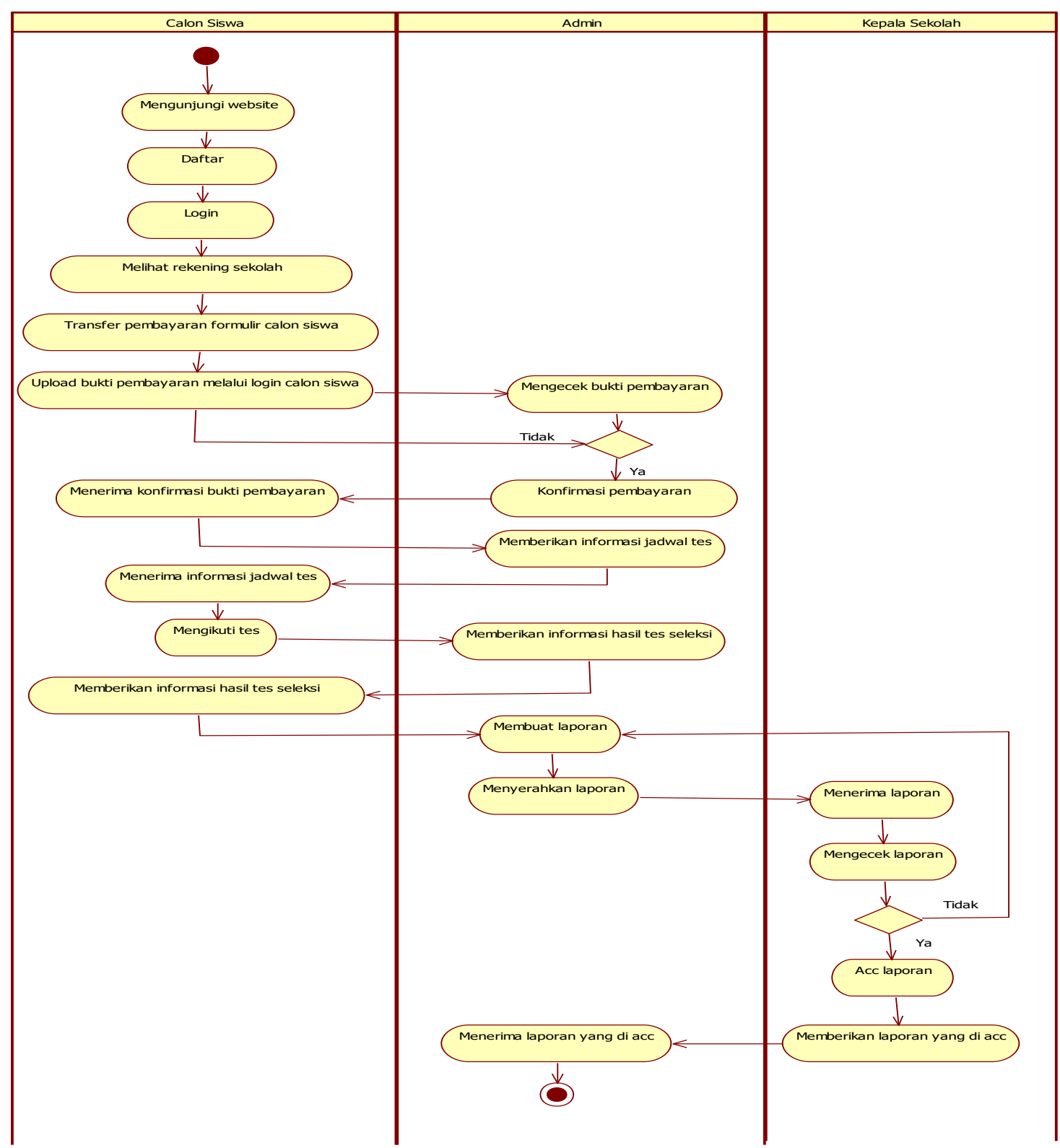

Sumber: Hasil Penelitian (2019)

Gambar 4. Activity Diagram Sistem Berjalan 
Sebagaimana disajikan pada gambar 4, kemudian calon siswa membayar formulir kepada admin, admin mengisi kwitansi pembayaran formulir dan memberikan kwitansi kepada calon siswa, setelah itu siswa menerima kwitansi yang diberikan oleh admin, kemudian admin memberikan formulir pendaftaran kepada calon siswa, calon siswa mengisi formulir pendaftaran yang sudah diberikan oleh admin, setelah sudah di isi calon siswa memberikan formulir pendaftaran nya kepada admin, kemudian admin menerima formulir pendaftaran yang sudah di isi dari calon siswa dan admin memberikan jadwal tes untuk calon siswa, calon siswa menerima jadwal tes yang sudah diberikan oleh admin dan mengikuti tes, setelah itu admin memberikan informasi hasil seleksi calon siswa lewat mading sekolah, kemudian calon siswa melihat informasi hasil seleksi di mading sekolah, setelah itu admin membuat laporan untuk diserahkan kepada kepala sekolah, kemudian kepala sekolah menerima laporan yang sudah diberikan admin, jika laporan tidak ada kesalahan kepala sekolah akan acc laporan dan memberikan laporan kepada admin, tapi jika laporan salah admin di minta untuk membuat laporan kembali.

\subsection{Perancangan Sistem}

Pada tahap ini merupakan tahapan merancang sistem sesuai dengan kebutuhan dengan menggunakan diagram ERD, Sequence diagram dan activity diagram.

Tabel 1. Spesifikasi Tabel Pembayaran

\begin{tabular}{llllll}
\hline No & Elemen Data & Nama Field & Tipe & Size & Keterangan \\
\hline 1 & Id pembayaran & id_pembayaran & Int & 5 & Primary key \\
\hline 2 & Id pendaftaran & id_pendaftaran & Int & 5 & Foreign key \\
\hline 3 & Foto pembayaran & pembayaran_foto & varchar & 50 & \\
\hline 4 & Tanggal pembayaran & pembayaran_tanggal & Date & & \\
\hline 5 & Status pembayaran & pembayaran_status & Enum \\
Sumber: & Hasil Penelitian (2019) & & & \\
& Spesifikasi tabel terdiri dari nama tabel pembayaran, akronim
\end{tabular}
pendaftaran_pembayaran, menyimpan data pembayaran yang diterima, organisasi file indexed sequential, akses file random, media file harddisk, panjang record 60 karakter, field id_pembayaran, software XAMPP.

Pada gambar 5 merupakan sistem usulan pendaftaran siswa SMK Tinta Emas Indonesia tahapan pendaftaran dimulai calon siswa melakukan pendaftaran dengan cara login ke halaman web.

Kemudian memasukkan username dan password yang diterima oleh admin. Selanjutnya calon siswa melakukan konfirmasi pembayaran pada menu yang telah disediakan pada sistem. Jika sudah selesai konfirmasi pembayaran admin melakukan validasi tahapan selanjutnya dapat mengaksess menu informasi jadwal tes sehingga dapat mengikuti ujian.

Admin memasukkan data siswa yang lulus ujian masuk penerimaan siswa baru setelah itu calon siswa dapat mengakses hasil penerimaan siswa untuk mengetahui lulus atau tidak dalam ujian penerimaan siswa baru.

Tahapan terakhir admin membuat laporan siswa yang diterima yang sudah melalui tahap ujian masuk kepada kepala sekolah untuk ditandatangani. 


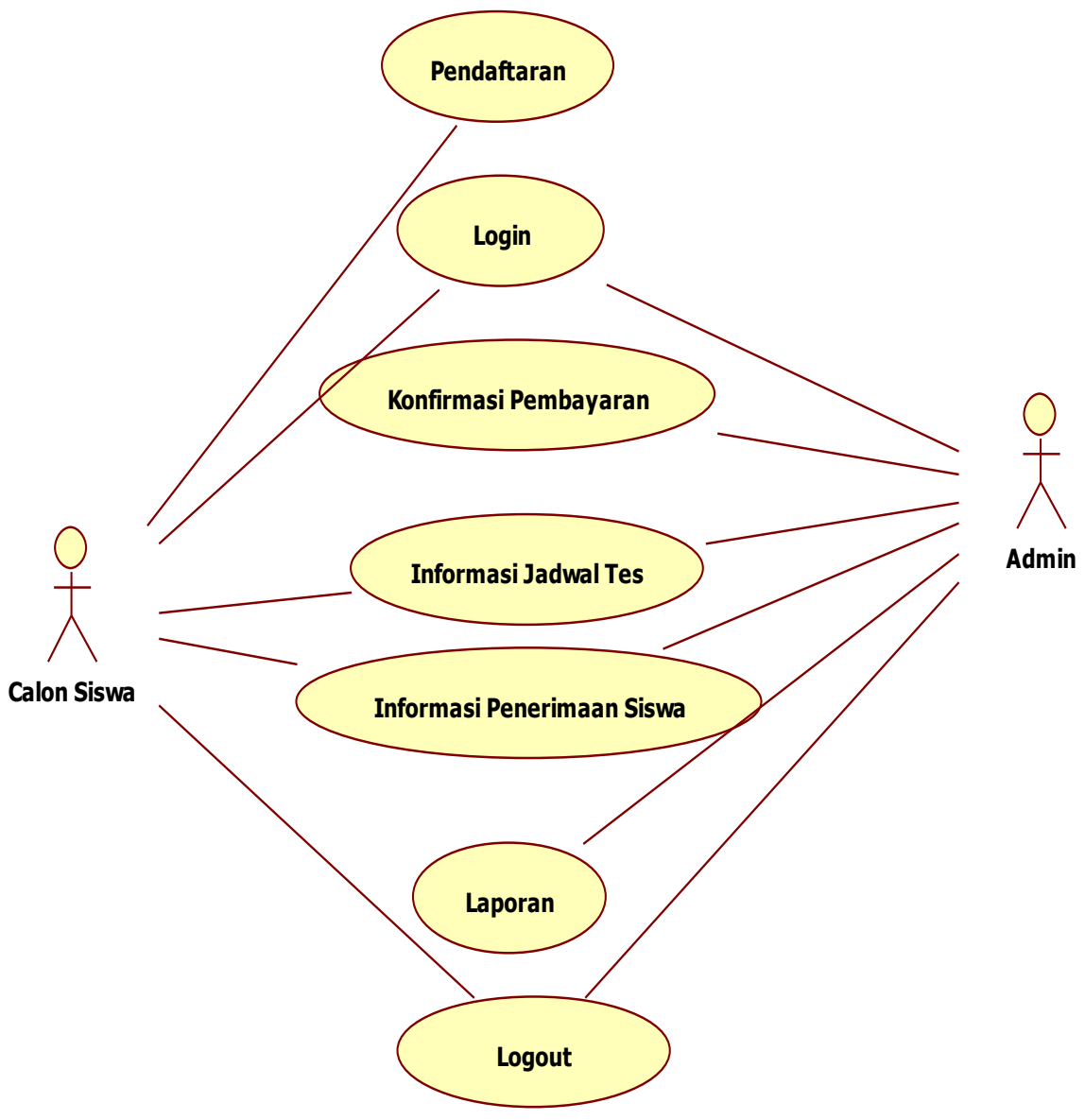

Sumber: Hasil Penelitian (2019)

Gambar 5. Use Case Diagram Sistem Usulan Pendaftaran Siswa SMK Tinta Emas Indonesia

Pada Tabel 2 merupakan scenario pendaftaran pada sistem, dengan use case name pendaftaran, dengan Actor calon siswa, Description menjelaskan proses untuk melakukan pendaftaran calon siswa.

Tabel 2. Scenario Pendaftaran

\begin{tabular}{|c|c|}
\hline Aksi Aktor & Reaksi Sistem \\
\hline $\begin{array}{l}\text { 2. Klik pendaftaran } \\
\text { 4. Mengisi form pendaftaran, } \\
\text { 5. Klik simpan }\end{array}$ & $\begin{array}{l}\text { 1. Menampilkan halaman menu utama } \\
\text { 3. Menampilkan form pendaftaran } \\
\text { 6. Tersimpan ke database }\end{array}$ \\
\hline \multicolumn{2}{|c|}{ Scenario Alternatif (Proses Gagal) } \\
\hline 2. Mengisi kembali form & $\begin{array}{l}\text { 1. Data tidak bisa disimpan } \\
\text { 3. Bila sudah terisi semua sistem menampilkan menu utama. }\end{array}$ \\
\hline Kondisi Akhir & Dapat melakukan pendaftaran \\
\hline
\end{tabular}

\subsection{Implementasi Program}

Dalam tahapan implementasi program merupakan pembuatan sistem informasi pendaftaran siswa menggunakan framework Codeigniter database menggunakan MySQL. Gambar 6 merupakan menu utama pendaftaran siswa baru. 


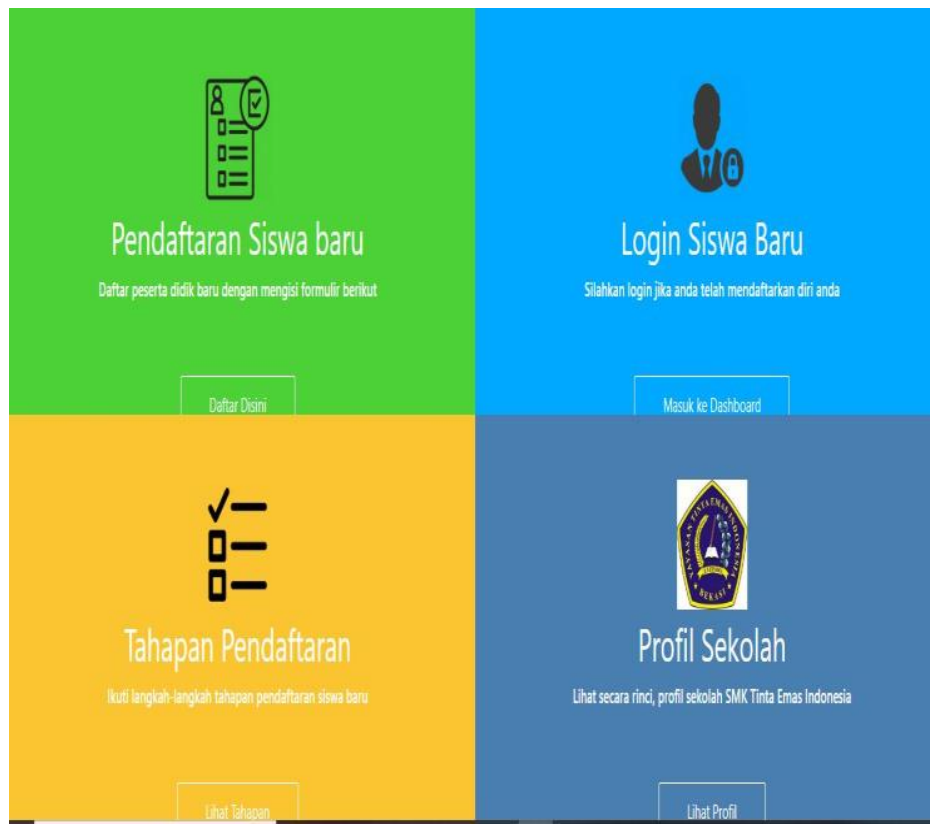

Sumber: Hasil Penelitian (2019)

Gambar 6. Form Menu Utama Pendaftaran Siswa Baru

Form menu utama pendaftaran siswa adalah form yang menampilkan halaman utama website pada pendaftaran siswa yang terdiri dari menu pendaftaran siswa baru, login siswa baru, login siswa baru dan profil sekolah.

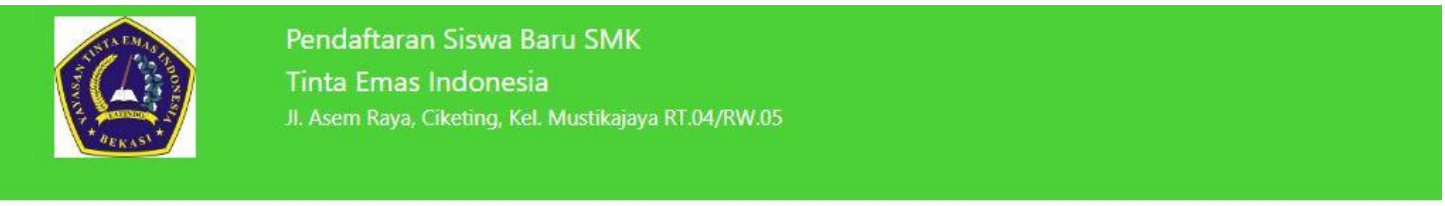

PENTING! Pastikan anda mengisi semua field berbintang $\left(^{*}\right)$ untuk menyimpan data pendaftaran anda!

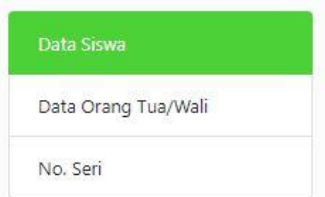

Data Siswa

NISN *

Asal Sekolah*
SMP 26 Bekasi
+ Tambah Sekolah Lain
Tinggal Bersama
Orang Tua
Telepon *
No. Telepon..
Jumlah Saudara
Jumlah Saudara..

Sumber: Hasil Penelitian (2019)

Gambar 7. Form Pendaftaran Siswa Baru

Pada gambar 7 merupakan form isian pendaftaran siswa baru yang terdiri dari NISN, passwor, nama lengkap, jenis kelamin, asal sekolah, tinggal bersama, telepon dan jumlah saudara setelah semua di isi lalu klik simpan pendaftaran. 


\subsection{Pengujian Sistem}

Dalam pengujian sistem informasi pendaftaran siswa baru menggunakan black box testing yang terfokus pada proses masukan dan keluaran program. Tabel 3 merupakan pengujian terhadap form login siswa.

Tabel 3. Hasil Pengujian Form Login Siswa

\begin{tabular}{|c|c|c|c|c|c|}
\hline No & Skenario Pengujian & Test Case & $\begin{array}{l}\text { Hasil } \\
\text { diharapkan }\end{array}$ & $\begin{array}{l}\text { Hasil } \\
\text { Pengujian }\end{array}$ & Kesimpulan \\
\hline 1 & $\begin{array}{l}\text { NISN dan password } \\
\text { tidak diisi kemudian } \\
\text { klik tombol login. }\end{array}$ & $\begin{array}{l}\text { NISN (Kosong) } \\
\text { Password } \\
\text { (Kosong) }\end{array}$ & $\begin{array}{lr}\text { Sistem } & \text { akan } \\
\text { menolak akses } & \text { user } \\
\text { dan tetap akan } \\
\text { menampilkan form } \\
\text { login. }\end{array}$ & $\begin{array}{l}\text { Sesuai } \\
\text { Harapan }\end{array}$ & Valid \\
\hline 2 & $\begin{array}{l}\text { Mengetik NISN dan } \\
\text { password tidak diisi } \\
\text { kemudian } \\
\text { tombok login. }\end{array}$ & $\begin{array}{l}\text { NISN (123456) } \\
\text { Password } \\
\text { (kosong) }\end{array}$ & $\begin{array}{ll}\text { Sistem } & \text { akan } \\
\text { menolak akses } & \text { user } \\
\text { dan tetap akan } \\
\text { menampilkan form } \\
\text { login. }\end{array}$ & $\begin{array}{l}\text { Sesuai } \\
\text { Harapan }\end{array}$ & Valid \\
\hline 3 & $\begin{array}{l}\text { NISN tidak diisi dan } \\
\text { mengetik password } \\
\text { kemudian klik } \\
\text { tombol login. }\end{array}$ & $\begin{array}{l}\text { NISN (kosong) } \\
\text { Password } \\
(1234567)\end{array}$ & $\begin{array}{lr}\text { Sistem } & \text { akan } \\
\text { menolak akses } & \text { user } \\
\text { dan tetap akan } \\
\text { menampilkan form } \\
\text { login. }\end{array}$ & $\begin{array}{l}\text { Sesuai } \\
\text { Harapan }\end{array}$ & Valid \\
\hline 4 & $\begin{array}{l}\text { Mengetik NISN dan } \\
\text { password kemudian } \\
\text { klik tombol login. }\end{array}$ & $\begin{array}{l}\text { Username } \\
(123456) \\
\text { Password } \\
(1234567)\end{array}$ & $\begin{array}{lr}\text { Sistem } & \text { akan } \\
\text { menerima } & \text { akses } \\
\text { login } & \text { dan } \\
\text { menampilkan data. }\end{array}$ & $\begin{array}{l}\text { Sesuai } \\
\text { Harapan }\end{array}$ & Valid \\
\hline
\end{tabular}

Pengujian pada form pendaftaran ini dilakukan untuk mengurangi kesalahan atau kekurangan pada sistem yang akan diimplementasikan pada saat pendaftaran siswa baru, disajikan pada tabel 4 .

Tabel 4. Hasil Pengujian Form Pendaftaran Siswa Baru

\begin{tabular}{|c|c|c|c|c|c|c|}
\hline No & Skenario Pe & ngujian & Test Case & Hasil Yang diharapkan & $\begin{array}{l}\text { Hasil } \\
\text { Pengujian }\end{array}$ & Kesimpulan \\
\hline 1 & $\begin{array}{l}\text { Tidak } \\
\text { biodata } \\
\text { bertanda }\left({ }^{*}\right)\end{array}$ & $\begin{array}{r}\text { mengisi } \\
\text { yang }\end{array}$ & $\begin{array}{l}\text { NISN *(Kosong) } \\
\text { Agama * } \\
\text { (Kosong). }\end{array}$ & $\begin{array}{l}\text { Sistem akan menolak } \\
\text { akses user dan tidak } \\
\text { dapat menyimpan data } \\
\text { tersebut }\end{array}$ & $\begin{array}{l}\text { Sesuai } \\
\text { Harapan }\end{array}$ & Valid \\
\hline 2 & $\begin{array}{l}\text { Mengisi } \\
\text { biodata } \\
\text { bertanda }\left({ }^{*}\right)\end{array}$ & $\begin{array}{r}\text { semua } \\
\text { yang }\end{array}$ & $\begin{array}{l}\text { NISN* (123456) } \\
\text { Agama * (Islam). }\end{array}$ & $\begin{array}{l}\text { Sistem akan menerima } \\
\text { askses dan menyimpan } \\
\text { data tersebut }\end{array}$ & $\begin{array}{l}\text { Sesuai } \\
\text { Harapan }\end{array}$ & Valid \\
\hline
\end{tabular}

\subsection{Analisis SWOT}

Analisis SWOT adalah suatu bentuk identifikasi didalam di dalam organisasi yang dilakukan secara sistematis sehingga dapat membantu merumuskan suatu rencana atau strategi sehingga matang baik jangka pendek maupun jangka panjang. Berikut analisis SWOT pada SMK Tinta Emas Indonesia Bekasi:

\section{Kekuatan (Strenghts)}

Kekuatan SMK Tinta Emas Indonesia Bekasi yaitu sistem yang mudah digunakan karna masih menggunakan sistem manual, sumber daya manusia dan pengajar profesional dalam bidangnya, lokasi yang strategis, serta biaya sekolah yang relatif murah, motivasi guru dan siswa cukup tinggi sehingga mampu mengembangkan metode pembelajaran yang efektif dan 
disertai dengan penerapan iman dan takwa sehingga siswanya cukup antusias dalam merespon setiap pembelajaran.

\section{Kelemahan (Weakness)}

Kelemahan SMK Tinta Emas Indonesia Bekasi yaitu belum bisa memfasilitasi sarana dan prasarana yang mendukung untuk pembelajaran terutama di perpustakaan.

\section{Peluang (Opportunities)}

Peluang bagi SMK Tinta Emas Indonesia Bekasi adalah pertumbuhan calon siswa yang meningkat, peminat yang selalu meningkat setiap tahun, sarana dan prasarana merupakan kekuatan yang telah ada agar bisa dipergunakan dan pemanfaatannya yang ada harus di kembangkan terus.

\section{Hambatan (Threats)}

Meningkatnya kreativitas dan inovasi dalam merekrut peserta didik baru oleh sekolah lain, Kurangnya fasilitas perpustakaan yang memadai, meningkatnya permintaan kebutuhan dari calon siswa, naiknya harga sumber daya untuk mendukung keberlangsungan proses belajar mengajar yang lebih baik.

\subsection{Analisa faktor kelayakan TELOS}

TELOS adalah Technical, Economic, Legal, Operational dan Schedule. Berikut ini adalah penjelasan faktor kelayakan TELOS dalam penelitian.

\section{Technical}

Pada kelayakan technic berkaitan dengan teknologi yang ada atau teknologi yang baru jika dibutuhkan yang nantinya akan diusulkan dan diterapkan pada sistem yang akan dikembangkan. Dalam penelitian yang dilakukan pada penerimaan siswa baru SMK Tinta Emas Indonesia, rancangan sistem yang akan dibuat adalah teknologi baru yang membutuhkan teknologi internet.

\section{Economics}

Pada penilaian kelayakan economic, membutuhkan dana yang memadai untuk menunjang biaya implementasi dari sistem yang diusulkan. Dalam penelitian ini dibutuhkan dana untuk implementasi jaringan internet dan server serta dibutuhkan juga untuk dana untuk perawatan berkala.

Legal

Pada penilaian kelayakan legal, adanya sistem baru juga harus dipertimbangkan dalam menunaikan kewajibannya. Penerapan sistem penerimaan siswa baru berbasis website didukung software yang digunakan harus memiliki lisensi original sebagai bentuk tanggung jawab sekolah.

\section{Operational}

Dalam penilaian kelayakan operational, menunjukan apakah sumber daya manusia yang tersedia dapat mengoprasikan sistem yang akan dibuat atau perlu diberikan keterampilan tambahan. Sistem informasi yang akan dibuat akan memudahkan admin dalam bekerja dan 
tetap dibutuhkan pelatihan serta diberikan petunjuk prosedur sistem untuk memudahkan user dalam memahami sistem informasi yang akan dibuat.

\section{Schedule}

Pada penilaian kelayakan schedule, pengadaan sistem yang diusulkan harus berada dalam kerangka waktu yang ideal, rentang waktu tersebut melingkupi perencanaan, pengembangan, implementasi, serta uji coba. Pengukuran estimasi kesalahan dalam pembuatan sistem dibutuhkan untuk membuat kelayakan jadwal. Untuk sistem informasi pada Penerimaan Siswa Baru Bekasi terbilang sederhana dan estimasi waktu yang dibutuhkan untuk pembangunan sistem adalah dalam kurun waktu satu hingga tiga bulan.

Jumlah semua faktor kelayakan adalah 31 dengan total nilai akhir faktor kelayakan TELOS $31 / 9=3.44$, yang berarti peracangan sistem informasi penerimaan siswa baru pada SMK Tinta Emas Indonesia adalah layak.

\section{Kesimpulan}

Adapun kesimpulan yang dapat peneliti kemukakan dalam skripsi ini dengan adanya Sistem Informasi Penerimaan Siswa Baru Pada SMK Tinta Emas Indonesia Bekasi, Dengan adanya sistem informasi penerimaan berbasis website ini, calon siswa tidak harus menunggu formulir di sekolah, dapat memberikan informasi yang akurat dalam menyampaikan pengumuman, dapat membantu dan bermanfaat bagi pihak sekolah dan calon siswa dalam pembuatan laporan yang akurat dan waktu efektif. Saran yang dapat diberikan untuk pengembangan Sistem Informasi Penerimaan Siswa Baru Berbasis Web Pada SMK Tinta Emas Indonesia Bekasi yaitu sarana dan prasarana, dimana sistem ini dibuat pastinya membutuhkan sarana dan prasarana pendukung seperti laptop atau personal computer serta printer. Diperlukan pelatihan khusus terhadap user dalam menggunakan atau mengoprasikan program aplikasi ini, karena untuk mengoptimalkan kerja sehingga tidak terjadi kesalahan yang dapat merusak program. Merancang sistem keamanan sehingga sistem tidak dirusak oleh orang yang tidak bertanggung jawab.

\section{Daftar Pustaka}

Fathansyah. (2015). Basis Data. Informatika Bandung.

Jelantik, K. A. . (2015). Menjadi Kepala Sekolah yang Profesional Panduan Menuju PKKS. Deepublish.

Kholifah, U., \& Wardati, I. U. (2014). Sistem Informasi Pendaftaran Peserta Didik Baru Pada Sekolah Menengah Kejuruan Negeri 1 Sudimoro. IJNS - Indonesian Journal on Networking and Security, 3(3), 50-54. https://doi.org/10.1123/IJNS.V3I3.1254

Muslihudin, M., \& Oktafianto. (2016). Analisis dan Perancangan Sistem Informasi Menggunakan Model Terstruktur dan UML. Andi.

Sukamto, R. A., \& Shalahuddin, M. (2014). Rekayasa Perangkat Lunak Terstruktur dan Berorientasi Objek. Informatika. 
Utomo, P., \& Ariyanti, D. (2014). Sistem Informasi Pembayaran dan Pendaftaran Siswa Baru Berbasis Web. Jurnal Sisfotek Global, Vol. 4(No. 2), 4-6.

Widianto, D., \& Yulianto, L. (2014). Sistem Informasi Pendaftaran Peserta Didik Baru Pada Sekolah Menengah Kejuruan (SMK) Negeri 2 Pacitan Berbasis Web Dinamis. Indonesian Journal on Networking and Security, 3(3), 320-326. https://doi.org/10.1111/j.17447348.1949.tb06928.x

Widodo, A. W., \& Kurnianingtyas, D. (2017). Sistem Basis Data. UB Press.

Witanto, R., \& Solihin, H. H. (2016). Perancangan Sistem Informasi Penerimaan Siswa Baru Berbasis Web ( Studi Kasus: Smp Plus Babussalam Bandung ). Jurnal Teknologi Informasi Dan Komunikasi, 1(1), 54-63. https://doi.org/https://doi.org/10.1234/jtik.v6i2.107 Yasin, V. (2012). Rekayasa Perangkat Lunak Berorientasi Objek. Mitra Wacana Media. 